\title{
Alcohol preparation compared to traditional surgical hand antisepsis: acceptance by surgical team at a private hospital in Brazil
}

\author{
JY Kawagoe ${ }^{1,2^{*}}$, AR Toniolo ${ }^{3}$, CV Silva ${ }^{3}$, FG Menezes ${ }^{3}$, M Hutter $^{4}$, P Zimmer ${ }^{4}$, L Barbosa ${ }^{5}$, L Correa ${ }^{3}$, Camila Santos ${ }^{3}$, \\ Leonilda Pontes ${ }^{3}$, Helena Castagna ${ }^{3}$, Maria F Cardoso ${ }^{3}$, Priscila Gonçalves ${ }^{3}$
}

From 3rd International Conference on Prevention and Infection Control (ICPIC 2015)

Geneva, Switzerland. 16-19 June 2015

\section{Introduction}

Traditional surgical hand scrubbing (TSHS) has been replaced by alcohol-based formulation (ABF) in many countries due to antimicrobial efficacy, easy application, lower skin damage, time saver and no recontamination risk by rinsing hands with water [1]. In Brazil, chlorhexidine (CHG) and povidone-iodine (PVPI) are used for TSHS.

\section{Objectives}

Compare one ABF to TSHS, evaluating surgical team acceptance and time, water, products and waste savings.

\section{Methods}

This before-after intervention evaluation, quantitative study was conducted in two operating suites (26 rooms) at a 650-bed private hospital - São Paulo, Brazil. The ABF approved for surgical hand antisepsis by ASTM-E1115, CEN-EN 12791 and Brazilian Health Surveillance Agency was available for 12-week (May-July/2014). The subjects that met inclusion criteria answered two questionnaires: before and after $\mathrm{ABF}$ introduction, evaluating the following attributes: softness, dryness, irritation, skin feel, easiness in putting on surgical gloves, drying time, etc. Chi-square and McNemar tests were used. Time and water consumption were also measured.

\section{Results}

$52(55.9 \%)$ subjects completed the study. The majority were male $(34 ; 65.4 \%)$, age of $36-55$ years and $>16$ years performing surgery $(31 ; 59.6 \%)$. ABF was considered excellent/good by 47 (90.4\%). Procedure simplifier/time saver, good fragrance, soft/comfortable/hydrated hands skin, non-abrasive/non-irritating were evaluated positively, $\mathrm{p}<0.001$. There were per person/hand antisepsis: approximately 73 seconds' time saving, an average of 33.1 liters of water consumption saving and waste saving (surgical brushes/sterile towels).

\section{Conclusion}

The ABF for surgical hand antisepsis had an excellent/ good acceptance by the members of surgical team. It results in considerable savings in water and healthcare associated residues as the environment is concerned.

\section{Disclosure of interest}

J. Kawagoe Grant/Research support from: GOJO - Provision of alcoholic products and techinical and administrative support, A. Toniolo: None declared, C. Silva: None declared, F. Menezes: None declared, M. Hutter: None declared, P. Zimmer: None declared, L. Barbosa Employee of: GOJO - Provision of alcoholic products and techinical and administrative support, L. Correa: None declared.

\footnotetext{
Authors' details

${ }^{1}$ Nursing Post-graduation Course, Albert Einstein Nursing Faculty, Sao Paulo, Brazil. ${ }^{2}$ Infection Control Service, Hospital Israelita Albert Einstein, Sao Paulo, Brazil. Infection Control Service, Albert Einstein Hospital, São Paulo, Brazil. ${ }^{4}$ Surgical Center, Albert Einstein Hospital, São Paulo, Brazil. ${ }^{5}$ GOJO, Sao Paulo, Brazil.
}

Published: 16 June 2015 


\section{Reference}

1. Widmer AF, Rotter M, Voss A, Nthumba P, Allegranzi B, Boyce J, Pittet D: Surgical hand preparation: state-of-the-art. Journal of Hospital Infection 2010, 74:112e122.

doi:10.1186/2047-2994-4-S1-P163

Cite this article as: Kawagoe et al:: Alcohol preparation compared to traditional surgical hand antisepsis: acceptance by surgical team at a private hospital in Brazil. Antimicrobial Resistance and Infection Control 2015 4(Suppl 1):P163

Submit your next manuscript to BioMed Central and take full advantage of:

- Convenient online submission

- Thorough peer review

- No space constraints or color figure charges

- Immediate publication on acceptance

- Inclusion in PubMed, CAS, Scopus and Google Scholar

- Research which is freely available for redistribution

Submit your manuscript at www.biomedcentral.com/submit
Ciomed Central 